Назимко С.С., Щербіна А.В. - Основні показники кримінально протиправної...

\title{
ОСНОВНІ ПОКАЗНИКИ КРИМННАЛЬНО ПРОТИПРАВНОї ДІЯЛЬНОСТІ У СФЕРІ НЕЗАКОННОГО ВТРУЧАННЯ В РОБОТУ АВТОМАТИЗОВАНОÏ СИСТЕМИ ДОКУМЕНТООБІГУ СУДУ
}

НАЗИМКО Сгор Сергійович - доктор юридичних наук, старший науковий співробітник, перший проректор Донецького державного університету внутрішніх справ

ЩЕРБІНА Артем Валентинович - аспірант кафедри кримінального права та кримінології факультету № 1 Донецького державного університету внутрішніх справ)

У статті автор розглядає основні показники кримінально протиправної діяльності у сбері правосуддя. Особлива увага приділяеться кримінальному правопорушенню, яке полягає у незаконному втручанні в роботу автоматизованой системи документообігу суду. Автор вказує, шо блок кримінальних правопорушень проти правосуддя є відносно новим та формувався законодавцем у зв'язку із необхідністю захистити судовий процес від умисного заподіяння шкоди з метою приховати ті чи інші дані. Криміналізація иих суспільно небезпечних діянь обумовлена потребою убезпечити громадян та державу від беномену, котрий спровокує беззаконня, свавілля та стане каталізатором зростання рівня кримінально протиправної діяльності. Таким чином, кримінальні правопорушення проти правосуддя - це єдиний вид протиправних діянь, які не тільки бактом свого існування погіршують кримінологічну картину, а і сприяють іншим суспільно небезпечним діянням, порушуючи нормальне функиіонування судової системи.

Доводиться, шо встановлення адекватної картини кримінально протиправної діяльності у сфері правосуддя значно ускладнено ї латентністю. Існування прихованих випадків правопорушень у сбері правосуддя - це нонсенс. Однак викриття такого роду випадків може викликати хаос та дестабілізацію судової системи, зневірення громадян тощо. При иъому очевидним є той бакт, шоо органам, які відповідають за реалізаиію правосуддя, легше приховати випадки протиправної діяльносmі, сбальсифікувати дані тощо. Саме тому держава наразі потребує у перегляді санкиій статей, у яких передбачено відповідальність за посягання на судову систему та правосуддя.

Підсумовується, що сучасна Украӥна ще не може говорити про завершення прочесу приведення законодавства до вимог міжнародноі та європейсъкої правової спільноти. Нестабільна кримінологічна ситуаиія, регулярна поява нових борм суспільно небезпечних діянь (прикладом яких є незаконне втручання в роботу автоматизованої системи документообігу суду) вимагає від нормотвориів динамізму, гнучкості та «здорового» азарту. Кримінальні правопорушення проти правосуддя, а особливо діяння, передбачене ст. 376-1 КК Украӥни, виходячи з аналітичних та статистичних даних, залишаються актуальними та потребують перегляду в частині заходів та засобів кримінально-правового впливу.

Ключові слова: автоматизована система документообігу суду, кримінальне правопорушення, правосуддя, незаконне втручання, кримінальне законодавство, досудове розслідування, латентність, кримінологічна ситуація.

\section{Постановка проблеми}

Вивчення того чи іншого кримінально протиправного діяння потребує ретельного дослідження кожного феномену, котрий певним чином обумовлює/сприяє вчиненню. Одним із головних етапів є встановлен- 


\section{Кримінальне право, кримінальний процес та криміналістика}

ня детермінаційного комплексу та загальна кримінологічна оцінка, котра передбачає розгляд основних показників кримінально протиправної діяльності у певній сфері. Не є винятком і кримінальні правопорушення проти правосуддя, одним із яких є незаконне втручання в роботу автоматизованої системи документообігу суду. Вивчення судової практики та статистики, викладеної на сайті Генеральної прокуратури України свідчить про актуальність цього суспільно небезпечного діяння при його відносно незначній розповсюдженості. Стрімкий технічний прогрес, який має наслідком розростання інформаційних систем, формує не в повній мірі сприятливий прогноз щодо ймовірного зростання у майбутньому випадків протиправного посягання на автоматичні системи документообігу суду. Вказане свідчить про необхідність ретельного вивчення кримінологічної ситуації відносно вказаного суспільно небезпечного діяння.

\section{Аналіз останніх досліджень та публікацій}

На сьогодні кримінальне правопорушення, передбачене ст. 376-1 КК України, залишається не в повній мірі дослідженим. Окремі аспекти зустрічаються в працях таких учених, як В.I. Саранюк, В.А. Козак, О.В. Федорчук та ін.

Метою статті $є$ дослідження основних показників кримінально протиправної діяльності у сфері правосуддя, особливо незаконного втручання в роботу автоматизованої системи документообігу суду.

\section{Виклад основного матеріалу}

Взагалі, першим етапом на шляху протидії злочинності у сфері правосуддя є формування комплексної характеристики цієї категорії злочинів. Кримінально-правова наука насамперед визначає, які суспільно небезпечні діяння є злочинами. У результаті кримінально-правова характеристика надається не злочинності як явищу, а окремому злочину і містить аналіз окремих елементів, що утворюють склад злочину: об'єкт, об'єктивна сторона, суб'єкт та суб'єктивна сторона злочину. Інакше кажучи, на відміну від кримінології, де об'єктом дослідження є злочинність як явище, кримінальне право дає характеристику складу злочину, наявність якого в суспільно небезпечному діянні, вчиненому особою, є підставою притягнення цієї особи до кримінальної відповідальності [1, с. 239]. ...кримінологічна характеристика охоплює кількісно-якісні показники окремої групи (виду) злочинів, дані, що характеризують особистість злочинця, причини й умови вчинення відповідної групи злочинів, а також заходи попереджувального впливу [2, с. 4]. При цьому ми не можемо заперечувати той факт, що лише міцний тандем кримінального права та кримінології дозволяє встановити максимально небезпечні кримінальні правопорушення, дослідити їх структуру, географію, кількісно-якісні показники тощо. Це дозволить законодавцеві зробити спробу позитивно вплинути на ситуацію шляхом перегляду санкцій окремих статей кримінального законодавства.

Сучасні вчені висловлюють позицію, що основою побудови системи попередження певної групи злочинів є саме їх кримінологічна характеристика. Кримінологічна характеристика, на відміну від кримінальноправової або криміналістичної характеристик, найбільш повно враховує типові відомості про особу злочинця та жертву злочинного посягання, використовувані злочинні механізми тощо, які мають принципове значення, з точки зору організації попередження злочинів цього виду, встановлення та викриття винних осіб. I на відміну від кримінально-процесуальної характеристики, в основу якої покладено узагальнений предмет доказування, кримінологічна характеристика окремих видів злочинів насичена конкретним якісним знанням у формі інформаційно-статистичних зведень. При цьому зміст кримінологічної характеристики передбачає не конкретизацію предмета доказування, а розгляд типових ознак окремих елементів злочинної діяльності цього виду [3, с. 22]. Насправді, необхідно відмітити, що весь блок кримінальних правопорушень проти правосуддя є відносно новим та формувався законодавцем у зв'язку із необхідністю захистити судовий процес від умисного заподіяння шкоди з метою приховати 
ті чи інші дані. Якщо абстрактно розглядати криміналізацію цих суспільно небезпечних діянь, можна побачити, що вона обумовлена потребою убезпечити громадян та державу від феномену, котрий спровокує беззаконня, свавілля та стане каталізатором зростання рівня кримінально протиправної діяльності. Таким чином, кримінальні правопорушення проти правосуддя - це єдиний вид протиправних діянь, які не тільки фактом свого існування погіршують кримінологічну картину, а і сприяють іншим суспільно небезпечним діянням, порушуючи нормальне функціонування судової системи.

Якісні показники злочинності характеризують внутрішні особливості цього явища, закономірності іiї розвитку. Основним якісним комплексним показником $є$ структура злочинності. $\mathbb{E}$ досить багато визначень поняття «структура злочинності», наприклад: «...це групування злочинів і осіб, які їх вчинили, за певними їх якісними ознаками для установлення найбільш характерних рис із метою подальшого виявлення i вивчення взаємозв'язків між структурними підрозділами» $[4$, с. 58]; «...це внутрішня, притаманна їй ознака, що розкриває ії будову, окремі складові частини в загальній їх сукупності за визначений відрізок часу та на визначеній території» [5, с. 68]; це якісний показник, сутність якого полягає в описі співвідношення між групами і видами злочинів, вчинених різними категоріями правопорушників [6, с. 62]. У межах обраної тематики більш цінним для нас $є$ встановлення саме кількісного показника, котрий надасть можливість довести необхідність перегляду статті, якою передбачено кримінальну відповідальність за незаконне втручання в роботу автоматизованої системи документообігу суду.

О.М. Джужа, підтримуючи думку Н.Ф. Кузнєцової [7, с. 29], для аналізу структури злочинності вказує на використання таких показників [5, с. 68-69]: - співвідношення видів злочинів за їхньою класифікацією, поданою в Особливій частині КК; - питома вага найпоширеніших злочинів; - співвідношення видів злочинів за домінантною мотиваційною спрямованістю (насильницькі, корисливі, корисливо-насильницькі та необережні); - питома вага злочинності неповно- літніх; - питома вага групової злочинності, а всередині іiі - організованої; - питома вага рецидиву; - «географія» злочинності, тобто розподіл ії̈ за регіонами й типами населених пунктів; - питома вага злочинів, пов'язаних 3 незаконним обігом зброї; - питома вага злочинів, пов'язаних з незаконним обігом наркотиків; - «вуличні» злочини; - транснаціональні злочини. Отже, структура злочинності як комплексний показник включає значну кількість показників, за якими здійснюється аналіз злочинності, а тому доцільно всю сукупність показників згрупувати, у зв'язку з чим деякі автори наводять і відповідне визначення поняття «структура злочинності» - «... це якісна характеристика, що характеризує іiі внутрішню будову як співвідношення між групами (видами) злочинів, які можна аналізувати за кримінально-правовими, соціально-демографічними або кримінологічними критеріями» [8, с. 42].$\mathrm{B}$ нашому випадку нас цікавить окреме кримінальне правопорушення, котре полягає у незаконному втручанні в роботу автоматизованої системи документообігу суду. Однак, важливим $є$ встановлення кореляційних зв'язків вказаного діяння з іншими, розміщеними у тому самому розділі чинного Кримінального кодексу України. Ми не можемо не зазначити, що досліджуване нами правопорушення достатньо відрізняється від «сусідніх», оскільки його вчинення пов'язано не тільки із посяганням на судову систему, а і на кібербезпеку, тобто воно, фактично, $є$ ще і комп'ютерним кримінальним правопорушенням.

Інші науковці також поділяють структуру злочинності на три групи показників і безпосередньо вживають терміни «кримінально-правова структура», «соціальнодемографічна структура», «кримінологічна структура» [6, с. 63], а В.В. Голіна вживає терміни «кримінально-правові», «кримінологічні» i «соціально-демографічні» ознаки структури злочинності [4, с. 58]. I все ж таки, узагальнюючи підходи кримінологів до розуміння структури злочинності, необхідно констатувати той факт, що визначення цього поняття зводяться до безпосереднього розкриття його сутності як комплексного якісного показника, а саме відображення бу- 


\section{Кримінальне право, кримінальний процес та криміналістика}

дови злочинності. Отже, структура злочинності обмежена часовими i просторовими рамками (у межах певної держави) і включає сукупність показників (ознак), за якими здійснюється її поділ на кримінально-правову, соціально-демографічну, кримінологічну [9, с. 119]. У нашому дослідженні більші цінною є кримінально-правова структура, яку ми розглядаємо як сукупність факторів, які обумовлюють зростання кількісно-якісного показника по кожному окремому кримінальному правопорушенню: недосконалість санкції статті, неактуальність встановлених особливостей вчинення кримінального правопорушення тощо. Хоча ми ні в якому разі не применшуємо значення кримінологічного аналізу та його безпосередній вплив на будь-яке кримінально-правове дослідження.

Вимірювання та аналіз злочинності є одним із головних дослідницьких завдань як вітчизняної, так і зарубіжної кримінології. Він ускладнений через деякі фактори, один iз яких - стан кримінального законодавства більшості сучасних держав, за якого майже всі дорослі громадяни протягом життя вчиняють правопорушення, а іноді й не один раз. Такий феномен можна визначити як «надмірність кримінального закону». Це свідчить про те, що реєструють лише незначну кількість учинених злочинів. Незареєстровані злочини належать до латентної злочинності, виявлення й оцінка масштабів якої - завдання трудомістке і важкореалізовуване на практиці. Деякі вчені стверджують, що зареєстрована (врахована) злочинність «представницька» для всієї сукупності злочинів [10, с. 38]. У ній відображається ситуація зі злочинністю в цілому. Aле наскільки можна довіряти репрезентативності такої злочинності? Адже реєстрація часто залежить від активності населення (наскільки воно, включаючи жертв злочинів, достовірно повідомляе відповідні органи про вчинений злочин) [10, с. 38]. Звичайно, на сьогодні встановлення адекватної картини кримінально протиправної діяльності проти правосуддя значно ускладнено їі латентністю. Насправді, останнє твердження може викликати скепсис, пояснений тим, що це нонсенс - існування прихованих випадків правопорушень у сфері правосуддя. Однак, це не дивно, оскільки викриття такого роду випадків може викликати хаос та дестабілізацію судової системи, зневірення громадян тощо. При цьому очевидним є той факт, що органам, які відповідають за реалізацію правосуддя, легше приховати випадки протиправної діяльності, сфальсифікувати дані тощо. Саме тому держава наразі потребує у перегляді санкцій статей, у яких передбачено відповідальність за посягання на судову систему та правосуддя.

Від належної діяльності міліції (поліції; наскільки вона повно й точно реєструє всі факти злочинів, які стали їй відомі), від державної політики (що саме, на думку влади, є головним об'єктом боротьби зі злочинністю; від характеру злочинів (чи завжди населенню і поліції стають відомі факти шахрайства, екологічних злочинів, фальсифікації товарів і послуг). У всьому світі добре відома селективність (вибірковість) поліції та кримінальної юстиції при виявленні, реєстрації та розкритті злочинів: найбільш повно враховуються так звані street crimes (вуличні або «загальнокримінальні» злочини) і «не помічається» злочинність «респектабельна», «елітарна», «білокомірцева» (white-collar crime) [11]. У сучасних розвинутих країнах існуе кілька систем обліку вчинених злочинів, які взаємодоповнюють одна одну. Насамперед - це офіційна поліцейська (прокурорська, судова) статистика, що використовується в усіх країнах. Вона формується за різними критеріями: за кількістю затриманих підозрюваних, порушених кримінальних справ, зареєстрованих злочинів. Іноді за основу беруть не всі зареєстровані злочини, а найнебезпечніші або найпоширеніші [10, с. 38]. Варто звернути увагу на те, що статистичні дані не завжди в повній мірі відображають реальну кримінологічну ситуацію, оскільки ми не можемо забувати про «людський» фактор та те, що певна інформація може бути просто загублена або викривлена. Як свідчить статистика, кримінальні правопорушення проти правосуддя є достатньо розповсюдженими, однак, 3 іншого боку, уваги потребує незначний процент кримінальних правопорушень такого роду, по факту вчинення яких було складе- 
но обвинувальний вирок. Так, відповідно до даних, викладених на сайті Генеральної прокуратури України, у 2013 році було обліковано 10270 фактів правопорушень проти правосуддя, із них - 4144 з обвинувальним вироком (40\% від загальної кількості), у 2014 обліковано 8640 фактів, із них 2984 3 обвинувальним вироком (35\%), у 2015 9693 , з обвинувальним вироком - $2400(24,8$ $\%)$, у $2016-9323$, з обвинувальним вироком - $1793(19,2 \%)$, у 2017 - 8589, з обвинувальним вироком - 1800 (21\%), у 2018 - 9514, 3 обвинувальним вироком - 1876 (19,7\%), у 2019 - 10310, з обвинувальним вироком 1877 (18,2\%), у 2020 - 6406, з обвинувальним вироком - 997 (15,5\%), станом на квітень 2021 року обліковано 2315 кримінальних правопорушень проти правосуддя, із них із обвинувальним вироком - 181 (7,8 \%) [12]. Першопричиною такої картини частіше за все стають клопотання про звільнення від кримінальної відповідальності, хвороба підозрюваних та невідоме місцезнаходження. Таким чином, ми бачимо яскраву невідповідність загостреної кримінологічної ситуації кримінально-правовим заходам та засобам протидії.

Оскільки офіційні статистичні дані поліції не повні, то в багатьох країнах їх доповнюють даними віктимологічних опитувань населення (victimology survey). Суть останніх - анонімне репрезентативне (представницьке) опитування жителів про те, чи були вони особисто або члени їхніх сімей жертвами злочинів за певний, що передує опитуванню, проміжок часу (за рік, півріччя, квартал), і якщо так, то яких саме. У США результати таких опитувань (National Crime Victimization Survey - NCVS) становлять друге найважливіше джерело відомостей про злочинність (разом із статистикою ФБР), а порівняння даних UCR і NCVS - предмет кримінологічних досліджень [13]. У випадку 3 незаконним втручанням у роботу автоматизованої системи документообігу суду, як і кримінальних правопорушень проти правосуддя взагалі, встановлення кола потерпілих та визначення їх ролі має бути значно облегшене та продуктивне.

В Україні національні віктимологічні опитування до цього часу не проводилися.
Регіональні опитування такого спрямування провели в деяких регіонах, і вони мали разовий характер [14, с. 33]. Слід також зазначити, що їх проводили різні авторські колективи за різними методиками, тому їх результати неможливо порівняти. Третім способом вимірювання масштабів злочинності $є$ метод самозвіту (Self-Report Survey). Він полягає в анонімному анкетному репрезентативному опитуванні населення з метою з'ясування того, чи вчинював опитуваний (респондент) будь-які кримінально карані діяння за певний період. Цей метод досить поширений за кордоном і майже не застосовується в Україні. Існують й інші національні або регіональні види досліджень, спрямовані на вирішення спеціальних завдань (визначення рівня насильницьких злочинів у регіоні, ступеня латентності тих чи інших злочинів тощо). Так, у США проводять національні дослідження молоді (National Survey of Youth), які дають змогу уточнити стан молодіжної злочинності. Нині в українській та світовій кримінології використовують такі основні показники, що характеризують стан і тенденції злочинності [10, с. 39]. Насправді, вчені вже давно підтвердили факт латентності кримінальних правопорушень проти правосуддя, що підтверджується низкою фактів.

Так, наприклад, аналіз даних Департаменту інформаційних технологій МВС України дає підстави для висновку, що значна кількість злочинів проти правосуддя або взагалі не реєструється або реєструються по інших видах злочинів. Зазвичай, це злочини у сфері службової діяльності. Такий висновок підтверджується багаточисельними скаргами свідків, потерпілих, підсудних на несправедливі судові рішення, процесуальні порушення на досудовому слідстві та при розгляді справ у судах. Зокрема, у 2008 році в органи прокуратури України надійшло більше 1000 скарг на застосування недозволених методів слідства, понад 13000 скарг на судові вироки та інші рішення у кримінальних справах, майже 11000 - по цивільних справах. У 2010 році до органів прокуратури надійшло 5979 скарг, які стосувалися вчинення злочинів проти правосуддя. В органи внутрішніх справ - ще 2 774. Із них, 


\section{Кримінальне право, кримінальний процес та криміналістика}

прийнято рішення про порушення кримінальної справи за 1416 заявах, з них органами внутрішніх справ - 353 [15, с. 176]. Вказані роки виділились найбільш наочними та яскравими статистичними даними, які підтверджують недієвість кримінального закону. Більше того, що стосується особливостей кваліфікації та розслідування незаконного втручання в роботу автоматизованої системи документообігу суду, варто звернути увагу, що органи досудового розслідування не завжди об'єктивно та правильно підходять до встановлення всіх елементів складу кримінального правопорушення, через що особа або звільняється від кримінальної відповідальності, або несе останню за інше, схоже суспільно небезпечне діяння. Ще одна проблема полягає у відносній новизні такого роду кримінального правопорушення, що ускладнюе його розслідування. Кримінальне правопорушення, передбачене ст. 376-1 КК України, є достатньо розповсюдженим та протягом останніх років залишається актуальним, про що свідчать статистичні дані, викладені на сайті Генеральної прокуратури України. Так, у 2013 році було вчинено 1 кримінальне правопорушення, передбачене ст. 376-1 КК України, у 2014 - 8, у 2015 - 18, у 2016 - 37, у 2017 - 60, у 2018 - 83, у 2019 - 34, у 2020 - 30, станом на березень 2021 року досліджуване нами протиправне діяння було вчинено 14 разів [12]. Взагалі, на нашу думку, першопричина латентності таких протиправних діянь криється у неефективній роботі правоохоронних органів.

Про це також свідчать і результати дослідження злочинів та інших правопорушень, учинених працівниками органів внутрішніх справ у 1992-2009 роках, проведеногоО. Мартиненком [16]. Відповідно до отриманих ним висновків, працівники міліції, як правило, засуджувались за умисні вбивства, тілесні ушкодження, зловживання владою, перевищення влади, а не за злочини проти правосуддя. Більше того, за незаконні методи ведення слідства, незаконне застосування спеціальних засобів, незаконні дії стосовно затриманих, незаконне адміністративне затримання, незаконне притягнення до кримінальної відповідальності, незаконний арешт вони притягувались до дисциплінар- ної відповідальності. Таким чином, високий рівень безкарності за злочини проти правосуддя є безпосереднім чинником, який обумовлює і високий рівень латентності таких злочинів. Слід також зазначити, що окремі злочини цієї категорії вчиняються на підгрунті усталених корупційних осередків, так званої кругової поруки, що склалася у системі правоохоронних органів. Цей фактор, 3 тих що впливають на латентність злочинів проти правосуддя, є визначальним. Потенційними фігурантами злочинних проявів проти правосуддя, передбачених статтями 371-375 КК України, є працівники правоохоронних органів і судів, які з огляду на своє службове становище спроможні безперешкодно приховувати окремі факти, події, обставини вчинюваних злочинів. Наслідком цього $є$ високий рівень латентності таких злочинів, оскільки саме правова обізнаність злочинців у мундирах має вирішальне значення на стадії первинної дослідчої перевірки та порушення кримінальних справ. Визначені фактори у сукупності 3 недосконалою системою реєстрації, обліку та статистичної звітності породжують певну недостовірність та необ'єктивність у відображенні фактичного стану злочинності у цій сфері [15, с. 175]. Ми абсолютно погоджуємось із вказаною думкою. При цьому доповнимо, що незаконне втручання в роботу автоматизованої системи документообігу суду дещо відрізняється за способом та суб'єктами від інших кримінальних правопорушень проти правосуддя.

Незважаючи на незначну питому вагу злочинів проти правосуддя в загальній масі зареєстрованих злочинів, їх суспільна небезпека від цього не зменшується. Поперше, злочини цієї категорії суттєво підривають авторитет держави в цілому, іï правоохоронних органів і судів, що породжує невпевненість суспільства у спроможності державних інституцій ефективно протистояти злочинності. По-друге, будь-яке застосування неправових методів у правоохоронній діяльності та діяльності судів з протидії злочинності породжуе в суспільстві правовий нігілізм, фактичне несприйняття принципу законності, як основного регулятора правоохоронної діяльності, а в поєднанні 3 
принципами верховенства права, то й здійснення правосуддя. Як наслідок, суспільство втрачає інтерес до участі в підтриманні законності. У правосвідомості людей зароджуються підвалини несприйняття діяльності органів правопорядку, а нерідко і їх осуду взагалі. По-трете, злочинам проти правосуддя, як ніяким іншим, характерна висока латентність. Обумовлюється вона високим рівнем корпоративності, притаманної для правоохоронної системи і судової діяльності, намірами (іноді взагалі не прикритими) керівників силових відомств, насамперед, МВС, СБУ, податкової міліції, держмитниці, а нерідко і суддів, з метою недопущення суспільного розголосу наявних фактів постановлення неправосудних рішень, тиску на свідків, фальсифікації доказів, не процесуальних способів здобування (вибивання) показань тощо. I навіть коли цього уникнути не вдається і справи доходять до судового розгляду, у таких випадках призначаються незначні покарання. Не можна не враховувати високий рівень корумпованості правоохоронної системи, використання службових повноважень у корисливих цілях. Усе це серйозно впливає на ефективність застосування кримінального закону [15, с. 176]. Дійсно, на сьогодні законодавець оминає увагою те, що, посягаючи на правосуддя, кримінальний правопорушник посягає, в першу чергу, на державу. Створення іміджу судової влади - складний та тривалий процес, котрий формує обличчя країни та іiі законодавця.

Отже, сучасна Україна ще не може говорити про завершення процесу приведення законодавства до вимог міжнародної та європейської правової спільноти. Нестабільна кримінологічна ситуація, регулярна поява нових форм суспільно небезпечних діянь (прикладом яких є незаконне втручання в роботу автоматизованої системи документообігу суду) вимагає від нормотворців динамізму, гнучкості та «здорового» азарту. Кримінальні правопорушення проти правосуддя, а особливо діяння, передбачене ст. 376-1 КК України, виходячи 3 аналітичних та статистичних даних, залишаються актуальними та потребують перегляду в частині заходів та засобів кримінально-правового впливу. На нашу думку, стабільно середній показник розповсюдженості кримінального правопорушення, передбаченого ст. 3761 КК України, пов'язаний із наступними факторами: 1) латентність, обумовлена (у більшості випадків) наявністю спеціальних знань, навичок та вмінь суб'єкта; лабільністю правоохоронних органів та незначною часткою випадків навмисного приховування такого роду фактів працівниками судів; 2) відносною новизною складу кримінального правопорушення та відсутністю адекватного способу реагування на нього; 3) складністю у встановленні всіх елементів складу кримінального правопорушення, що має наслідком неправильну кваліфікацію;4) відсутністю налагодженої процедури досудового розслідування такого роду суспільно небезпечних діянь; 5) недослідженим та недоопрацьованим феноменом впливу жертви на склад кримінального правопорушення.

\section{入ітература}

1. Фіалка M.I. До проблеми визначення змісту терміна «кримінологічна характеристика злочинності». Вісник Кримінологічної асоціації України. 2015. № 1(9). С. 239.

2. Алексеев А. И. Криминология: Курс лекций. Москва: Щит-М, 1998. 336 с.

3. Юхно О.О. Проблеми запобігання крадіжкам приватного майна громадян на пасажирському залізничному транспорті: монографія. Одеса: ОЮІ ХНУВС, 2006. $201 \mathrm{c}$.

4. Кримінологія : підруч. / В.В. Голіна та ін. ; за заг. ред. В.В. Голіни, Б.М. Головкіна. Харків : Право, 2014. 440 с.

5. Іванов Ю.Ф., Джужа О.М. Кримінологія : навч. посіб. вид. 2-е, допов. та перероб. Київ : Видавець Паливода А.В., 2008. 292 c.

6. Кримінологія : підруч. Практикум / В.С. Ковальський та ін. Київ : Юрінком Інтер, 2016. 336 с.

7. Кузнецова Н.Ф. Преступление и преступность. Москва : Изд-во Моск. ун-та, 1969. 232 c.

8. Кримінологія : питання та відповіді/ О.О. Авдєєв та ін. ; за заг. ред. О.М. Аитвинова. Харків : Золота миля, 2015. 323 c. 


\section{Кримінальне право, кримінальний процес та криміналістика}

9. Хаврук В. О. Якісні показники злочинності в україні: порівняльний аналіз за 2017-2018 pp. URL: http://nv.knutkt.edu. ua/index.php/2308-5053/issue/view/11839

10. Джужа О. М., Василевич В.В., Кулик О.Г. Основні показники злочинності: міжнародний і вітчизняний досвід. Вісник Верховного Суду Украӥни. 2012. № 1. С. 37-42.

11. Coleman J. The Criminal Elite: The Sociology of White Collar Crime. NY: St. Martin's Press, 1985; Podgor E. White Collar Crime in a Nutshell St Paul (Minn) : West Publishing Co, 1993.

12. Генеральна прокуратура України. URL: http: //www. gp.gov.ua/ua/stst2011.html? dir $\mathrm{id}=112173 \&$ libid $=100820 \& \mathrm{c}=$ edit\& $c=\overline{f o}$

13. Sheley J . Criminology Wadsworth, 2000. P. 60-79.

14. Бова А.А. Соціологічні опитування потерпілих від злочинів в Україні. Украӥнсъкий соиіум. 2006. С. 33-34

15. Кальман О.Г., Мірошниченко С.С. Кримінологічна характеристика злочинів проти правосуддя. Боротьба з організованою злочинністю $i$ корупиією (теорія $i$ практика). 2011. Вип. 24. С. 171-182.

16. Мартиненко О. Злочини працівників органів внутрішніх справ України : аналіз тенденцій 1992-2009 рр. Публічне право. № 2. 2011. С. 71-77 ; Мартиненко О. А. Детерминация и предупреждение преступности среди персонала органов внутренних дел Украины : монография. Х. : Изд-во ХНУВС, 2005. 496 c.

Shcherbina Artem, graduate student of the Department of Criminal Law and Criminology, Faculty

№ 1 (Donetsk State University of Internal Affairs)

MAIN INDICATORS OF CRIMINALLY

ILLEGAL ACTIVITY IN THE FIELD OF

ILLEGAL INTERFERENGE IN THE WORK

OF THE AUTOMATED COURT DOCUMENT SYSTEM

In the article the author considers the main indicators of criminally illegal activity in the field of justice. Particular attention is paid to the criminal offense, which consists in illegal interference in the work of the automated document management system of the court. The author points out that the block of criminal offenses against justice is relatively new and was formed by the legislator in connection with the need to protect the trial from intentional harm in order to hide certain data. The criminalization of these socially dangerous acts is due to the need to protect citizens and the state from the phenomenon that will provoke lawlessness, arbitrariness and will be a catalyst for increasing the level of criminal activity. Thus, criminal offenses against justice are the only type of illegal acts that not only worsen the criminological picture by their existence, but also contribute to other socially dangerous acts, disrupting the normal functioning of the judicial system. It turns out that establishing an adequate picture of criminally illegal activity against justice is significantly complicated by its latency. This is nonsense - the existence of hidden cases of offenses in the field of justice. However, exposing such cases can cause chaos and destabilization of the judiciary, public despair, and so on. At the same time, it is obvious that it is easier for the bodies responsible for the administration of justice to hide cases of illegal activity, falsify data, etc. That is why the state now needs to review the sanctions of articles that provide for liability for encroachment on the judiciary and justice. It is concluded that modern Ukraine cannot yet talk about completing the process of bringing legislation to the requirements of the international and European legal community. The unstable criminological situation, the regular emergence of new forms of socially dangerous acts (an example of which is the illegal interference in the work of the automated court document management system) requires dynamism, flexibility and "healthy" passion from lawmakers. Criminal offenses against justice, and especially the act provided by Art. 376-1 of the Criminal Code of Ukraine, based on analytical and statistical data remain relevant and need to be revised in terms of measures and means of criminal law.

Key words: automated court document management system, criminal offense, justice, illegal intervention, criminal legislation, pre-trial investigation, latency, criminological situation. 